\title{
HUBUNGAN AKTIVITAS FISIK DENGAN KEJADIAN OBESITAS PADA ORANG DEWASA DI INDONESIA
} (Analisis Data Riskesdas 2007)

\author{
Sudikno, ${ }^{1}$ Milla Herdayati ${ }^{2}$ dan Besral ${ }^{2}$ \\ ${ }^{1}$ Puslitbang Gizi dan Makanan, Bogor \\ 2Departemen Biostatistik Fakultas Kesehatan Masyarakat UI
}

\begin{abstract}
ASSOCIATION BETWEEN PHYSICAL ACTIVITY AND ADULT OBESITY IN INDONESIA

(Secondary Data Analysis of the Basic Health Research 2007)
\end{abstract}

The enhancement of social economy status and the life style changes, including changes in eating habits and reduction of physical activities, increased overweight and obesity prevalence. This paper aims to study the association between physical activity and adult obesity in Indonesia. This research used Basic Health Research (Riset Kesehatan Dasar) 2007 data with cross-sectional design. The populations were all household members aged $\geq 18$ years, whereas the samples were all household members aged $\geq 18$, physically and mentally healthy, non-pregnant, and their BMI were at least $18.5 \mathrm{~kg} / \mathrm{m}^{2}$. The respondent was obese if his/her BMI was at least $18.5 \mathrm{~kg} / \mathrm{m}^{2}$. Physical activity was assessed with questions about its type (vigorous and moderate) and its duration per week. Logistic regression was used to study the relationship between physical activity and adult obesity. The result showed that Obesity prevalence $\left(B M \mid>27 \mathrm{~kg} / \mathrm{m}^{2}\right)$ in adult was $12.47 \%$ ( $\mathrm{Cl} 95 \%$ : $12.28-12.66$ ). The result showed there was a relationship between physical activity and adult obesity, controlled by confounder variable (area, age, sex, marital status, education, occupation, and smoking habits). People who had low level of physical activity had more risk to be obese than those who had high level physical activity. It has been recommended that to reduce the risk of being obese, it is advisable to have sufficient physical activity such as walking, jogging, running, and biking. It is also necessary for the Ministry of Health to develop guidance of sufficient physical activity.

Keywords: obesity, adult, physical activity

\section{PENDAHULUAN}

$\mathrm{K}$ elebihan berat badan dan kegemukan (obesitas) merupakan faktor risiko dari berbagai penyakit degeneratif, seperti diabetes tipe 2, hipertensi, penyakit jantung, dan kanker. ${ }^{1}$ Asosiasi Jantung Amerika (AHA) ${ }^{2}$ mengidentifikasi obesitas sebagai faktor risiko utama dari penyakit jantung koroner. Kenaikan berat badan setelah usia dewasa muda berhubungan dengan peningkatan risiko kejadian penyakit jantung koroner. ${ }^{3}$ Studi kohor pada orang dewasa muda menunjukkan bahwa mereka yang berat badannya meningkat lebih dari 2,5 $\mathrm{kg}$ dalam 15 tahun mengalami peningkatan dalam faktor risiko penyakit jantung koroner dan tingginya angka kejadian sindrom metabolik dan komponennya, seperti lemak dan tekanan darah. ${ }^{4}$

Penelitian Jafar et al. ${ }^{5}$ di Pakistan yang dilakukan terhadap populasi berumur di atas 15 tahun juga menyimpulkan bahwa mereka yang kelebihan berat badan dan obesitas (IMT > 23 $\mathrm{kg} / \mathrm{m}^{2}$ ) memiliki risiko kejadian hipertensi dan diabetes tipe 2 dua kali lipat dibandingkan dengan yang ber-IMT normal. Demikian juga penelitian Mokdad et al. ${ }^{6}$ di Amerika Serikat menunjukkan bahwa kelebihan berat badan dan obesitas berhubungan secara signifikan dengan diabetes, tekanan darah tinggi, kolesterol, artritis, asma, dan status kesehatan yang buruk.

Adapun penelitian Wolk A et al. ${ }^{7}$ (2001) di Swedia terhadap 28129 pasien rumah sakit (8 165 laki-laki dan 19964 perempuan) menunjukkan bahwa pasien laki-laki dan perempuan yang obesitas cenderung mengalami kejadian kanker. Demikian juga studi Framingham, ${ }^{8}$ yang dilakukan terhadap 3 457 laki-laki dan perempuan, menunjukkan adanya penurunan umur harapan hidup yang berhubungan dengan kelebihan berat badan dan obesitas.

Sebagaimana diketahui bahwa prevalensi kelebihan berat badan dan obesitas di negara maju dan negara berkembang mengalami peningkatan. Di negara maju prevalensi kegemukan pada laki-laki dan perempuan pada tahun 2004 berkisar antara 23,2 persen di 
Jepang dan 66,3 persen di Amerika. Sementara di negara berkembang pada tahun 2000-2001 berkisar antara 13,4 persen di Indonesia sampai dengan 72,5 persen di Arab Saudi. Prevalensi obesitas di Vietnam pada tahun 2000 diketahui sebesar 2,52 persen pada laki-laki dan pada perempuan sebesar 5,73 persen. ${ }^{9}$

Survei kesehatan di Singapura tahun 1992 menunjukkan prevalensi obesitas cenderung meningkat dari 5,1 persen (tahun 1992) menjadi 6,9 persen (tahun 2004), walaupun tidak signifikan $(p=0,076) .10$ Di Malaysia, prevalensi kelebihan berat badan dan obesitas berdasarkan hasil survei kesakitan nasional tahun 1996 diketahui sebesar 20,7 persen dan 5,8 persen. ${ }^{11}$ Prevalensi kelebihan berat badan dan obesitas di China berdasarkan survei gizi nasional tahun 1982 dan tahun 1992 menunjukkan peningkatan pada dewasa muda dari 9,7 persen menjadi 14,9 persen di perkotaan. Adapun di perdesaan meningkat dari 6,2 persen menjadi 8,4 persen. ${ }^{12}$

Data prevalensi kelebihan berat badan dan obesitas secara nasional di Indonesia masih terbatas. Hasil survei Indeks Massa Tubuh (IMT) di Indonesia pada tahun 1996-1997 di 12 kotamadya di Indonesia mendapatkan prevalensi gizi lebih sebesar 10,3 persen dan prevalensi obesitas sebesar 12,2 persen, ${ }^{13}$ dan prevalensi gizi lebih ini mengalami peningkatan pada tahun 1999 sebesar 14 persen dan tahun 2000 sebesar 17,4 persen. ${ }^{14}$ Selanjutnya dari laporan Riset Kesehatan Dasar $2007^{15}$ menunjukkan prevalensi obesitas penduduk dewasa di Indonesia (umur 15 tahun ke atas) sebesar 10,3 persen.

Penyebab terjadinya kelebihan berat badan dan obesitas berkaitan dengan berbagai faktor, baik faktor yang tidak dapat diubah maupun faktor yang dapat diubah. Faktor risiko yang tidak dapat diubah meliputi: genetik, etnik, jenis kelamin, dan umur. Sementara faktor risiko yang dapat diubah adalah konsumsi makanan, gaya hidup, dan aktivitas fisik. ${ }^{16}$

Sebagaimana diketahui bahwa peningkatan status sosial ekonomi masyarakat erat kaitannya dengan perubahan gaya hidup, termasuk dalam perubahan pola makan. Konsumsi padi-padian menurun, sedangkan persentase energi dari konsumsi lemak meningkat. Di samping itu juga terjadi perubahan dalam kebiasaan makan keluarga, adanya kecenderungan keluarga untuk makan di luar rumah, dan adanya peningkatan konsumsi makanan cepat saji. Selanjutnya perubahan gaya hidup yang signifikan lainnya adalah aktivitas fisik yang cenderung menurun di masyarakat, termasuk masyarakat perdesaan. ${ }^{17}$ Perubahan pola makan dan menurunnya aktivitas fisik berakibat semakin banyaknya penduduk golongan tertentu mengalami masalah gizi lebih berupa kelebihan berat badan dan obesitas. ${ }^{18}$

Beberapa penelitian terkait dengan hubungan antara aktivitas fisik dan kejadian obesitas menunjukkan bahwa laki-laki dengan aktivitas fisik kurang mempunyai risiko obesitas sebesar 1,39 kali (Cl 95\%: 1,02-1,89), sedangkan perempuan dengan aktivitas fisik kurang mempunyai risiko obesitas sebesar 1,28 kali (Cl 95\%: 0,99-1,65). ${ }^{19}$ Selanjutnya dari hasil penelitian Kaplan et al. ${ }^{20}$ diketahui bahwa lakilaki dengan aktivitas fisik kurang mempunyai risiko obesitas sebesar 1,43 kali (Cl 95\%: 1,24$1,66)$ dan perempuan dengan aktivitas fisik kurang mempunyai risiko obesitas sebesar 1,27 kali (Cl 95\%: 1,14-1,42).

Laporan Riset Kesehatan Dasar (Riskesdas) tahun 2007 memberikan informasi mengenai keadaan kesehatan di Indonesia, termasuk persentase obesitas dan aktivitas fisik, tetapi analisis untuk mengetahui hubungan antara aktivitas fisik dengan obesitas pada orang dewasa belum dilakukan. Analisis tersebut diperlukan sebagai bahan masukan program gizi, baik di tingkat pusat maupun di daerah, terutama dalam penanganan masalah gizi lebih dan obesitas yang akhir-akhir ini cenderung meningkat. Tujuan penelitian ini adalah untuk mengetahui prevalensi obesitas pada orang dewasa di Indonesia dan mengetahui hubungan aktivitas fisik dengan obesitas pada orang dewasa dengan dikontrol oleh variabel wilayah, umur, jenis kelamin, status kawin, pendidikan, pekerjaan, kebiasaan merokok, dan kebiasaan makan.

\section{METODE PENELITIAN}

\section{Sumber data penelitian}

Data yang digunakan untuk penelitian ini adalah Riskesdas 2007. Populasi dalam Riskesdas 2007 adalah seluruh rumah tangga di Indonesia, sedangkan sampel rumah tangga dirancang identik dengan daftar sampel rumah 
tangga dan anggota rumah tangga Susenas 2007.

Kerangka pengambilan sampel menggunakan blok sensus (BS) dari Badan Pusat Statistik (BPS). Cara pengambilan sampel adalah cluster sampling dengan menggunakan blok sensus BPS. Rancangan sampel 2 tahap di daerah perkotaan dan 3 tahap di daerah perdesaan. Untuk rancangan sampel 2 tahap, tahap-1 dari kerangka sampel BS dipilih sejumlah BS secara PPS (probability proportional to size) menggunakan linear systematic sampling dengan size adalah banyaknya rumah tangga hasil listing di setiap BS hasil P4B (Pendaftaran Pemilih dan Pendataan Penduduk Berkelanjutan). Pada tahap-2, dari jumlah rumah-tangga hasil listing di tiap BS terpilih, dipilih 16 rumah tangga secara linear systematic sampling. Untuk rancangan sampel 3 tahap di daerah perdesaan, hampir sama dengan 2 tahap, hanya sesudah tahap-1 dibentuk sejumlah subBS. Selanjutnya dipilih satu sub-BS secara PPS dengan size banyaknya rumah tangga hasil listing di setiap sub-BS hasil P4B. Pada tahap3 , dari jumlah rumah tangga hasil listing di tiap BS terpilih, dipilih 16 rumah-tangga secara linear systematic sampling.

Dari laporan Riskesdas 2007 diketahui bahwa sampel yang telah berhasil dikumpulkan sebanyak 258386 sampel rumah tangga dan 987205 sampel anggota rumah tangga dari 440 kabupaten/kota di 33 provinsi di Indonesia. ${ }^{15}$

\section{Besar sampel penelitian}

Populasi dalam penelitian ini adalah semua anggota rumah tangga dalam Riskesdas 2007 yang berumur $\geq 18$ tahun. Adapun sampel adalah semua anggota rumah tangga Riskesdas 2007 yang berumur $\geq 18$ tahun dengan kriteria tidak cacat fisik dan mental, sampel wanita tidak dalam keadaan hamil, dan mempunyai Indeks Massa Tubuh (IMT) minimal $18,5 \mathrm{~kg} / \mathrm{m}^{2}$ (batas IMT normal menurut WHO, 2000 dan Depkes, 2003)2,14

\section{Data yang dikumpulkan}

Data yang dikumpulkan diambil dari kuesioner rumah tangga (RKD07.RT) yang meliputi pengenalan tempat dan keterangan anggota rumah tangga (wilayah, umur, jenis kelamin, status kawin, pendidikan, dan pekerjaan). Sementara dari kuesioner individu
(RKD07.IND) adalah kebiasaan merokok, aktivitas fisik, kebiasaan makan, dan pengukuran antropometri (berat badan dan tinggi badan). IMT merupakan perbandingan berat badan dan tinggi badan kuadrat dalam satuan $\mathrm{kg} / \mathrm{m}^{2}$, dikatakan obesitas jika IMT lebih dari $27 \mathrm{~kg} / \mathrm{m}^{2}$. Adapun aktivitas fisik terdiri dari aktivitas fisik berat, aktivitas fisik sedang, dan aktivitas berjalan kaki atau bersepeda. Dikatakan cukup bila melakukan aktivitas fisik sedang 5 hari per minggu selama 30 menit (150 menit per minggu) atau melakukan aktivitas fisik berat 3 hari per minggu selama 20 menit $(60$ menit per minggu) dan aktivitas berjalan kaki atau bersepeda 2 hari per minggu selama 10 menit (20 menit per minggu). Selanjutnya untuk mengetahui hubungan aktivitas fisik dan obesitas digunakan analisis regresi logistik model faktor risiko.

\section{Prosedur pengumpulan data}

Pengumpulan data dilakukan oleh tenaga lulusan Poltekkes atau petugas Dinas Kesehatan Kabupaten/Kota setempat yang terdiri dari empat orang pewawancara dan satu di antaranya menjadi ketua tim. Cara pengumpulan data meliputi wawancara dengan responden oleh petugas pengumpul data untuk mendapatkan informasi tentang pengenalan tempat dan keterangan anggota rumah tangga (wilayah, umur, jenis kelamin, status kawin, pendidikan, dan pekerjaan), kebiasaan merokok, aktivitas fisik, kebiasaan makan. Kemudian pengukuran antropometri (berat badan dan tinggi badan dilakukan setelah wawancara menggunakan timbangan berat badan merek AND dengan kapasitas $150 \mathrm{~kg}$ dan ketelitian 50 gram (baterai 3 A sebanyak 2 buah), dan untuk alat pengukur tinggi badan menggunakan MICROTOISE dengan kapasitas ukur 2 meter dan ketelitian $0,1 \mathrm{~cm}$.

Untuk mendapatkan kualitas data yang baik, maka selain dilakukan pelatihan petugas pengumpul data, juga dilakukan bimbingan teknis dan supervisi oleh Penanggung Jawab Tingkat Kabupaten/Kota (PJT Kabupaten/Kota), Penanggung Jawab Tingkat Provinsi (PJT Provinsi) dan tingkat pusat (Balitbangkes). Selanjutnya kuesioner untuk wawancara telah diuji-coba terlebih dahulu untuk mengetahui masalah dalam tingkat kesulitan, pemahaman bahasa dan istilah kesehatan, serta alur pertanyaan. Dan untuk meningkatkan validitas, 
maka alat pengukuran tinggi badan dan berat badan ditera sebelum digunakan. Selain itu dilakukan penggantian baterai untuk timbangan berat badan dalam periode tertentu.

\section{Manajemen dan analisis data}

Manajemen data meliputi penomoran, editing, pemrosesan data (data entry, dan cleaning). Pengolahan data diawali dengan mengonversi berat badan dan tinggi badan menjadi IMT, kemudian dibuat tabel sebaran sampel berdasarkan kelompok IMT menurut Depkes (2003), ${ }^{14}$ yaitu: IMT 27,0 kg/m² $\mathrm{ke}$ bawah (tidak obesitas) dan kelompok IMT lebih dari $27,0 \mathrm{~kg} / \mathrm{m}^{2}$ (obesitas). Di samping itu juga dilakukan weighting tiap record sesuai dengan nilai inflate yang telah tersedia dalam file. Weight dihitung berdasarkan nilai inflate tiap record dibagi dengan nilai rata-rata inflate.

Selanjutnya analisis data dilakukan secara bertahap, yaitu analisis univariate, bivariate, dan multivariate. Analisis univariate ditujukan untuk mengetahui sebaran nilai masing-masing variabel. Sementara analisis bivariate bertujuan untuk mengetahui hubungan dependent variable, yaitu obesitas dengan independent variable (aktivitas fisik, wilayah, umur, jenis kelamin, status kawin, pendidikan, pekerjaan, kebiasaan merokok, dan kebiasaan makan) dengan uji Chi-square. Tahap analisis multivariate ditujukan untuk mengetahui hubungan aktivitas fisik dengan obesitas dengan dikontrol oleh confounding variables (wilayah, umur, jenis kelamin, status kawin, pendidikan, pekerjaan, kebiasaan merokok, dan kebiasaan makan) dengan menggunakan analisis regresi logistik model faktor risiko. Semua analisis di atas menggunakan perangkat lunak statistik.

\section{HASIL}

\section{Karakteristik responden}

Penelitian ini melibatkan 484785 responden yang dianalisis. Hasil penelitian menunjukkan prevalensi obesitas (IMT lebih dari $\left.27 \mathrm{~kg} / \mathrm{m}^{2}\right)$ sebesar 12,47 persen $(\mathrm{Cl}$ 95\%:
12,28-12,66). Rata-rata IMT adalah 23,01 $\mathrm{kg} / \mathrm{m}^{2}$ dengan standar deviasi $\pm 3,34 \mathrm{~kg} / \mathrm{m}^{2}$. IMT minimal sebesar $18,5 \mathrm{~kg} / \mathrm{m}^{2}$ dan IMT maksimal sebesar $49,9 \mathrm{~kg} / \mathrm{m}^{2}$.

Tabel 1 menunjukkan distribusi responden menurut karakteristik variabel. Dilihat dari aktivitas fisik yang dilakukan responden tampak bahwa lebih dari separuh responden $(60,57 \%)$ kurang melakukan aktivitas fisik. Responden di perdesaan $(54,56 \%)$ lebih banyak daripada responden di perkotaan $(45,44 \%)$. Sebagian besar responden berumur 31-65 tahun $(67,68 \%)$ dan hanya 32,32 persen berumur $18-$ 30 tahun. Menurut jenis kelamin diketahui bahwa persentase responden laki-laki $(47,60 \%)$ hampir sama dengan perempuan $(52,40 \%)$. Adapun dilihat dari status kawin diketahui bahwa sebagian besar responden, yaitu 84,22 persen sudah kawin/janda/duda.

Menurut pendidikan tampak bahwa sebagian besar responden berpendidikan SD ke bawah (52,14\%), SMP (17,58\%), dan 30,28 persen responden berpendidikan SMA ke atas. Sementara dilihat dari jenis pekerjaan menunjukkan bahwa responden yang bekerja sebagai petani/buruh/nelayan, yaitu sebesar 34,27 persen. Responden tidak bekerja (sekolah, pensiunan, dan ibu rumah tangga) sebesar 34,09 persen, dan responden yang bekerja sebagai TNI/PNS/BUMN hanya 4,73 persen.

Dari kebiasaan merokok, diketahui bahwa sebagian besar responden tidak merokok $(64,83 \%)$ dan responden yang merokok sebesar 35,17 persen. Selanjutnya menurut kebiasaan makan sayuran dan buah tampak bahwa baru sekitar separuh responden (52,13\%) yang dikelompokkan cukup dalam mengonsumsi sayuran dan buah. Adapun dilihat dari kebiasaan responden dalam mengonsumsi makanan berlemak diketahui bahwa sebagian besar responden, yaitu sebesar 83,57 persen mengonsumsi makanan berlemak kurang dari 7 kali/minggu, dan hanya 16,43 persen yang mengonsumsi makanan berlemak 7 kali/minggu atau lebih. 
Tabel 1

Distribusi Responden menurut Karakteristik Variabel, Riskesdas 2007

\begin{tabular}{|c|c|c|c|c|}
\hline \multicolumn{3}{|c|}{ Karakteristik Variabel } & \multicolumn{2}{|c|}{ Jumlah $(n=484785)$} \\
\hline & & & $\mathrm{N}$ & $\%$ \\
\hline \multirow[t]{2}{*}{ Aktivitas fisik } & o & Kurang & 288239 & 60,57 \\
\hline & ० & Cukup & 196546 & 39,43 \\
\hline \multirow[t]{2}{*}{ Wilayah } & 0 & Perkotaan & 186168 & 45,44 \\
\hline & o & Perdesaan & 298617 & 54,56 \\
\hline \multirow[t]{2}{*}{ Umur (tahun) } & o & $18-30$ & 163477 & 32,32 \\
\hline & 0 & $31-65$ & 321308 & 67,68 \\
\hline \multirow[t]{2}{*}{ Jenis kelamin } & 0 & Perempuan & 251267 & 52,40 \\
\hline & ○ & Laki-laki & 233518 & 47,60 \\
\hline \multirow[t]{2}{*}{ Status kawin } & o & Kawin & 404411 & 84,22 \\
\hline & ○ & Belum kawin & 80374 & 15,78 \\
\hline \multirow[t]{3}{*}{ Pendidikan } & o & $\leq \mathrm{SD}$ & 247005 & 52,14 \\
\hline & o & SMP & 88694 & 17,58 \\
\hline & o & SMA + & 149086 & 30,28 \\
\hline \multirow[t]{4}{*}{ Pekerjaan } & 0 & Petani/buruh/nelayan & 178272 & 34,27 \\
\hline & o & Pelayanan jasa/pedagang & 116522 & 26,91 \\
\hline & & TNI/PNS/BUMN & 27491 & 4,73 \\
\hline & o & Tidak bekerja & 162500 & 34,09 \\
\hline \multirow[t]{2}{*}{ Kebiasaan merokok } & o & Tidak merokok & 313021 & 64,83 \\
\hline & ○ & Merokok & 171764 & 35,17 \\
\hline \multirow{2}{*}{$\begin{array}{l}\text { Kebiasaan makan sayuran dan } \\
\text { buah }\end{array}$} & 0 & Kurang & 247014 & 47,87 \\
\hline & ○ & Cukup & 237771 & 52,13 \\
\hline \multirow{2}{*}{$\begin{array}{l}\text { Kebiasaan makan makanan } \\
\text { berlemak }\end{array}$} & o & $\geq 7 x /$ minggu & 65020 & 16,43 \\
\hline & $\circ$ & $<7 x /$ minggu & 419765 & 83,57 \\
\hline
\end{tabular}

\section{Gambaran aktivitas fisik responden menurut variabel kovariat}

Tabel 2 menunjukkan persentase aktivitas fisik responden menurut variabel kovariat. Persentase aktivitas fisik kurang di perkotaan $(68,42 \%)$ lebih banyak dibandingkan dengan di perdesaan $(54,03 \%)$. Dari variabel umur diketahui bahwa persentase aktivitas kurang lebih banyak pada kelompok umur 18-30 tahun $(64,74 \%)$ dibandingkan dengan kelompok umur 31-65 tahun (58,58\%). Menurut jenis kelamin tampak bahwa persentase aktivitas fisik kurang pada perempuan lebih banyak $(62,47 \%)$ dibandingkan dengan laki-laki (58,48\%). Persentase aktivitas fisik kurang pada responden yang belum kawin $(68,13 \%)$ lebih banyak daripada responden yang sudah kawin/janda/duda $\quad(59,15 \%)$. Sementara persentase aktivitas fisik kurang pada responden dengan pendidikan SMA ke atas
(70,98\%) lebih tinggi dibandingkan dengan responden dengan pendidikan $\leq$ SD $(53,90 \%)$ dan $\operatorname{SMP}(62,39 \%)$.

Menurut jenis pekerjaan responden diketahui bahwa persentase aktivitas fisik kurang tertinggi terdapat pada responden yang bekerja sebagai TNI/PNS/BUMN, yaitu sebesar 72,84 persen, sedangkan persentase aktivitas fisik kurang yang terendah terdapat pada responden yang bekerja sebagai petani/buruh/nelayan, yaitu sebesar 45,38 persen. Selanjutnya dilihat dari kebiasaan merokok tampak bahwa persentase aktivitas fisik kurang lebih tinggi pada responden yang tidak merokok $(63,17 \%)$ daripada responden yang merokok (55,77\%).

Dari kebiasaan makan responden menunjukkan bahwa persentase aktivitas fisik kurang lebih tinggi pada responden yang kurang mengonsumsi sayuran dan buah $(63,35 \%)$. 
Adapun pada responden yang mengonsumsi makanan berlemak, persentase aktivitas fisik kurang tampak tidak jauh berbeda antara responden yang mengonsumsi makanan berlemak kurang dari 7 kali/minggu dan responden yang mengonsumsi makanan berlemak $\geq 7 \mathrm{kali} /$ minggu (Tabel 2).

Tabel 2

Persentase Aktivitas Fisik menurut Variabel Kovariat, Riskesdas 2007

\begin{tabular}{|c|c|c|c|c|}
\hline \multicolumn{2}{|c|}{ Variabel Kovariat } & \multirow{3}{*}{$\begin{array}{c}n \\
186168\end{array}$} & \multicolumn{2}{|c|}{ Aktivitas fisik (\%) } \\
\hline & & & Kurang & Cukup \\
\hline \multirow[t]{2}{*}{ Wilayah } & Perkotaan & & 68,42 & 31,58 \\
\hline & - Perdesaan & 298617 & 54,03 & 45,97 \\
\hline \multirow[t]{2}{*}{ Umur (tahun) } & $\circ \quad 31-65$ & 321308 & 58,58 & 41,42 \\
\hline & $\circ \quad 18-30$ & 163477 & 64,74 & 35,26 \\
\hline \multirow[t]{2}{*}{ Jenis kelamin } & ○ Perempuan & 251267 & 62,47 & 37,53 \\
\hline & ○ Laki-laki & 233518 & 58,48 & 41,52 \\
\hline \multirow[t]{2}{*}{ Status kawin } & o Kawin & 404411 & 59,15 & 40,85 \\
\hline & ○ Belum kawin & 80374 & 68,13 & 31,87 \\
\hline \multirow[t]{3}{*}{ Pendidikan } & $0 \leq \mathrm{SD}$ & 247005 & 53,90 & 46,10 \\
\hline & ○ SMP & 88694 & 62,39 & 37,61 \\
\hline & ○ SMA + & 149086 & 70,98 & 29,02 \\
\hline \multirow[t]{4}{*}{ Pekerjaan } & $\begin{array}{ll}\circ & \text { Petani/buruh/nelayan }\end{array}$ & 178272 & 45,38 & 54,62 \\
\hline & ○ Pelayanan jasa/pedagang & 116522 & 67,87 & 32,13 \\
\hline & ○ TNI/PNS/BUMN & 27491 & 72,84 & 27,16 \\
\hline & ○ Tidak bekerja & 162500 & 68,37 & 31,63 \\
\hline \multirow[t]{2}{*}{ Kebiasaan merokok } & o $\quad$ Tidak merokok & 313021 & 63,17 & 36,83 \\
\hline & ○ Merokok & 171764 & 55,77 & 44,23 \\
\hline \multirow{2}{*}{$\begin{array}{l}\text { Kebiasaan makan sayuran } \\
\text { dan buah }\end{array}$} & o $\quad$ Kurang & 247014 & 63,35 & 36,65 \\
\hline & ○ Cukup & 237771 & 58,01 & 41,99 \\
\hline Kebiasaan makan & $0 \quad>=7 x /$ minggu & 65020 & 60,75 & 39,25 \\
\hline Makanan berlemak & $0<7 x /$ minggu & 419765 & 60,53 & 39,47 \\
\hline \multicolumn{2}{|l|}{ Jumlah } & 484785 & 60,57 & 39,43 \\
\hline
\end{tabular}

Hubungan aktivitas fisik dengan obesitas

Hasil analisis bivariat aktivitas fisik dengan kejadian obesitas menunjukkan bahwa persentase obesitas pada responden dengan aktivitas fisik kurang sebesar 13,36 persen lebih tinggi dibandingkan pada responden dengan aktivitas fisik cukup. Responden dengan aktivitas fisik kurang memiliki risiko kejadian obesitas sebesar 1,232 kali (Cl 95\%: 1,199$1,266)$ dibandingkan responden dengan aktivitas fisik cukup (Tabel 3 ).

\section{Hubungan variabel kovariat dengan obesitas}

Tabel 3 menunjukkan hubungan variabel kovariat dengan kejadian obesitas. Menurut variabel wilayah diketahui bahwa persentase obesitas di perkotaan, yaitu 15,99 persen lebih tinggi daripada di perdesaan (9,54\%). Responden di perkotaan memiliki risiko obesitas sebesar 1,804 kali (Cl 95\%: 1,747-1,863) dibandingkan dengan responden di perdesaan. Dilihat dari variabel umur tampak bahwa persentase obesitas pada responden dengan kelompok umur 31-65 tahun (14,87\%) hampir dua kali lipat dibandingkan dengan kelompok umur 18-30 tahun (7,47\%). Responden pada kelompok umur 31-65 tahun memiliki risiko obesitas sebesar 2,163 kali (Cl 95\%: 2,099$2,229)$ dibandingkan dengan responden pada kelompok umur 18-30 tahun. 
Selanjutnya dari variabel jenis kelamin tampak bahwa persentase obesitas pada responden perempuan lebih tinggi daripada lakilaki. Responden dengan jenis kelamin perempuan memiliki risiko obesitas sebesar 2,362 kali (Cl 95\%: 2,301-2,425) dibandingkan dengan responden laki-laki. Sedangkan menurut status kawin diketahui bahwa persentase obesitas pada responden yang sudah kawin tiga kali lipat dibandingkan dengan responden yang belum kawin. Responden yang sudah kawin memiliki risiko obesitas sebesar 3,272 kali (Cl 95\%: 3,111-3,442) dibandingkan dengan responden yang belum kawin.

Tabel 3

Hasil Analisis Bivariat Hubungan Aktivitas Fisik dan Kovariat dengan Obesitas, Riskesdas 2007

\begin{tabular}{|c|c|c|c|c|c|}
\hline Karakteristik & $\mathrm{n}$ & $\begin{array}{r}\text { Obesitas } \\
\% \\
\end{array}$ & $\begin{array}{c}\text { Tidak } \\
\text { Obesitas } \\
\% \\
\end{array}$ & OR & Cl 95\% \\
\hline \multicolumn{6}{|l|}{ Aktivitas fisik } \\
\hline ○ Kurang & 288239 & 13,36 & 86,64 & 1,232 & $1,199-1,266$ \\
\hline ○ Cukup & 196546 & 11,12 & 88,88 & & \\
\hline \multicolumn{6}{|l|}{ Wilayah } \\
\hline ○ Perkotaan & 186168 & 15,99 & 84,01 & 1,804 & $1,747-1,863$ \\
\hline$\circ \quad$ Perdesaan & 298617 & 9,54 & 90,46 & & \\
\hline \multicolumn{6}{|l|}{ Umur (tahun) } \\
\hline$\circ \quad 31-65$ & 321308 & 14,87 & 85,13 & 2,163 & $2,099-2,229$ \\
\hline$\circ \quad 18-30$ & 163477 & 7,47 & 92,53 & & \\
\hline \multicolumn{6}{|l|}{ Jenis kelamin } \\
\hline ○ Perempuan & 251267 & 16,70 & 83,30 & 2,362 & $2,301-2,425$ \\
\hline ○ Laki-laki & 233518 & 7,82 & 92,18 & & \\
\hline \multicolumn{6}{|l|}{ Status kawin } \\
\hline ○ Kawin & 404411 & 13,93 & 86,07 & 3,272 & $3,111-3,442$ \\
\hline$\circ \quad$ Belum kawin & 80374 & 4,71 & 95,29 & & \\
\hline \multicolumn{6}{|l|}{ Pendidikan } \\
\hline $0 \leq \mathrm{SD}$ & 247005 & 11,87 & 88,13 & 1 & \\
\hline$\circ \quad$ SMP & 88694 & 12,11 & 87,89 & 1,022 & $0,987-1,058$ \\
\hline ○ SMA + & 149086 & 13,73 & 86,27 & 1,181 & $1,146-1,217$ \\
\hline \multicolumn{6}{|l|}{ Pekerjaan } \\
\hline ○ Petani/buruh/nelayan & 178272 & 6,56 & 93,44 & 1 & \\
\hline ○ Pelayanan jasa/pedagang & 116522 & 13,82 & 86,18 & 2,282 & $2,199-2,368$ \\
\hline TNI/PNS/BUMN & 27491 & 19,90 & 80,10 & 3,538 & $3,359-3,726$ \\
\hline ○ Tidak bekerja & 162500 & 16,33 & 83,67 & 2,778 & $2,685-2,875$ \\
\hline \multicolumn{6}{|l|}{ Kebiasaan merokok } \\
\hline ○ Tidak merokok & 313021 & 15,29 & 84,71 & 2,294 & $2,227-2,363$ \\
\hline$\circ \quad$ Merokok & 171764 & 7,29 & 92,71 & & \\
\hline \multicolumn{6}{|l|}{$\begin{array}{l}\text { Kebiasaan makan sayuran dan } \\
\text { buah }\end{array}$} \\
\hline$\circ \quad$ Kurang & 247014 & 10,51 & 89,49 & 0,705 & $0,685-0,725$ \\
\hline o Cukup & 237771 & 14,28 & 85,72 & & \\
\hline \multicolumn{6}{|l|}{$\begin{array}{lll}\begin{array}{l}\text { Kebiasaan } \\
\text { berlemak }\end{array} & \text { makan } & \text { makanan } \\
\end{array}$} \\
\hline$\circ \quad \geq 7 x /$ minggu & 65020 & 14,33 & 85,67 & 1,213 & $1,171-1,257$ \\
\hline $0<7 x /$ minggu & 419765 & 12,11 & 87,89 & & \\
\hline
\end{tabular}


Kemudian menurut variabel pendidikan diketahui bahwa persentase obesitas cenderung meningkat seiring dengan tingginya pendidikan. Responden dengan pendidikan SMP memiliki risiko obesitas sebesar 1,022 kali (Cl 95\%: 0,987-1,058) dibandingkan dengan responden dengan pendidikan SD ke bawah. Sedangkan responden dengan pendidikan SMA ke atas memiliki risiko obesitas sebesar 1,181 kali (Cl 95\%: 1,146-1,217) dibandingkan responden dengan pendidikan SD ke bawah.

Dilihat dari variabel pekerjaan tampak bahwa persentase obesitas tertinggi terdapat pada responden yang bekerja sebagai TNI/PNS/BUMN, yaitu sebesar 19,90 persen. Responden dengan pekerjaan TNI/PNS/BUMN memiliki risiko obesitas sebesar 3,538 kali $(\mathrm{Cl}$ 95\%: 3,359-3,726) dibandingkan responden dengan pekerjaan petani/buruh/nelayan. Responden yang tidak bekerja memiliki risiko obesitas sebesar 2,778 kali (CI 95\%: 2,6852,875 ) dibandingkan responden dengan pekerjaan petani/buruh/nelayan. Sementara responden yang bekerja sebagai pelayanan jasa/pedagang memiliki risiko obesitas sebesar 2,199 kali (Cl 95\%: 2,199-2,368) dibandingkan responden dengan pekerjaan petani/buruh/nelayan (Tabel 3).
Menurut kebiasaan merokok diketahui bahwa persentase obesitas pada responden yang tidak merokok lebih tinggi daripada responden yang merokok. Responden yang tidak merokok memiliki risiko obesitas sebesar 2,294 kali (Cl 95\%: 2,227-2,363) dibandingkan dengan responden yang merokok. Sedangkan menurut kebiasaan makan sayuran dan buah menunjukkan bahwa persentase obesitas cenderung lebih tinggi pada responden yang cukup mengonsumsi sayuran dan buah. Responden yang kurang mengonsumsi sayuran dan buah memiliki risiko obesitas sebesar 0,705 kali ( $\mathrm{Cl} 95 \%$ : 0,685-0,725) dibandingkan dengan responden yang cukup mengonsumsi sayuran dan buah. Selanjutnya dari kebiasaan makan makanan berlemak diketahui bahwa persentase obesitas pada responden yang mengonsumsi makanan berlemak 7 kali/minggu atau lebih, lebih tinggi daripada responden yang mengonsumsi makanan berlemak kurang dari 7 kali/minggu. Responden yang mengonsumsi makanan berlemak $7 \mathrm{kali} /$ minggu atau lebih memiliki risiko obesitas sebesar 1,213 kali $(\mathrm{Cl}$ 95\%: 1,171-1,257) dibandingkan dengan responden yang mengonsumsi makanan berlemak kurang dari 7 kali/minggu (Tabel 3 ).

Tabel 4

Odds Rasio dan $\mathrm{Cl}$ 95\% Variabel Interaksi Model Akhir Hubungan Aktivitas fisik dengan Obesitas pada Orang Dewasa

\begin{tabular}{|c|c|c|}
\hline Variabel Interaksi & OR & $\mathrm{Cl} 95 \%$ \\
\hline \multicolumn{3}{|l|}{ Aktivitas fisik*jenis kelamin } \\
\hline ○ Aktivitas fisik | Perempuan & 1,291 & $1,168-1,426$ \\
\hline ○ Aktivitas fisik | Laki-laki & 1,599 & $1,496-1,710$ \\
\hline \multicolumn{3}{|l|}{ Aktivitas fisikpendidikan } \\
\hline$\circ$ Aktivitas fisik $\mid \leq S D$ & 1,599 & $1,496-1,710$ \\
\hline o Aktivitas fisik / SMP & 1,373 & $1,255-1,501$ \\
\hline$\circ$ Aktivitas fisik / SMA + & 1,418 & $1,293-1,558$ \\
\hline \multicolumn{3}{|l|}{ Aktivitas fisik*pekerjaan } \\
\hline - Aktivitas fisik | Petani/buruh/nelayan & 1,599 & $1,496-1,710$ \\
\hline ○ Aktivitas fisik | Pelayanan jasa/pedagang & 1,395 & $1,297-1,501$ \\
\hline - Aktivitas fisik | TNI/PNS/BUMN & 1,253 & $1,111-1,412$ \\
\hline ○ Aktivitas fisik | Tidak bekerja & 1,425 & $1,312-1,548$ \\
\hline \multicolumn{3}{|l|}{ Aktivitas fisikmerokok } \\
\hline ○ Aktivitas fisik | Tidak merokok & 1,391 & $1,277-1,515$ \\
\hline ○ Aktivitas fisik | Merokok & 1,599 & $1,496-1,710$ \\
\hline
\end{tabular}




\section{Pemodelan hubungan aktivitas fisik dengan obesitas}

Langkah pertama dalam strategi pemodelan untuk mengetahui hubungan aktivitas fisik dengan obesitas adalah membuat model yang mengikutsertakan semua potential confounder dan effect modifier dan selanjutnya dilakukan eliminasi effect modifier. Hasil analisis regresi logistik hubungan aktivitas fisik dengan obesitas pada orang dewasa dapat dilihat pada Tabel 4.
Dari pemodelan akhir tersebut dapat dijelaskan bahwa setelah dikontrol confounder variables (variabel wilayah, umur, jenis kelamin, status kawin, pendidikan, pekerjaan, dan kebiasaan merokok) diketahui risiko kejadian obesitas pada orang dewasa berbeda menurut jenis kelamin, pendidikan, pekerjaan, dan kebiasaan merokok (variabel interaksi).

Selanjutnya dapat diketahui nilai koefisien dari masing-masing variabel seperti terlihat pada Tabel 5.

Tabel 5

Nilai Koefisien Beta, Standar Error, Nilai z, dan Nilai p Model Akhir Hubungan Aktivitas fisik dengan Obesitas pada Orang Dewasa

\begin{tabular}{|c|c|c|c|c|c|}
\hline Variabel & B & $\begin{array}{c}\text { Standar } \\
\text { Error }\end{array}$ & $\mathrm{z}$ & $\mathrm{p}$ & $95 \% \mathrm{Cl}$ \\
\hline Aktivitas fisik & 0,469 & 0,034 & 13,82 & 0,000 & $0,403-0,536$ \\
\hline Wilayah & 0,407 & 0,017 & 23,35 & 0,000 & $0,373-0,441$ \\
\hline Umur & 0,621 & 0,017 & 36,04 & 0,000 & $0,587-0,655$ \\
\hline Jenis kelamin & 0,730 & 0,034 & 21,13 & 0,000 & $0,662-0,798$ \\
\hline Status kawin & 0,804 & 0,028 & 28,26 & 0,000 & $0,748-0,860$ \\
\hline \multicolumn{6}{|l|}{ Pendidikan } \\
\hline $0 \leq S D$ & ref & & & & \\
\hline ○ SMP & 0,152 & 0,029 & 5,19 & 0,000 & $0,095-0,210$ \\
\hline ○ SMA + & 0,124 & 0,029 & 4,24 & 0,000 & $0,066-0,182$ \\
\hline \multicolumn{6}{|l|}{ Pekerjaan } \\
\hline ○ Petani/buruh/nelayan & ref & & & & \\
\hline$\circ \quad$ Pelayanan jasa/pedagang & 0,761 & 0,029 & 25,60 & 0,000 & $0,702-0,819$ \\
\hline ○ TNI/PNS/BUMN & 1,088 & 0,051 & 21,31 & 0,000 & $0,988-1,188$ \\
\hline o Tidak bekerja & 0,671 & 0,029 & 23,06 & 0,000 & $0,614-0,728$ \\
\hline Kebiasaan merokok & 0,358 & 0,035 & 10,05 & 0,000 & $0,288-0,428$ \\
\hline Aktivitas*jenis kelamin & $-0,214$ & 0,041 & $-5,12$ & 0,000 & $-0,296--0,132$ \\
\hline Aktivitas℠P & $-0,152$ & 0,036 & $-4,20$ & 0,000 & $-0,224--0,081$ \\
\hline Aktivitas*SMA+ & $-0,120$ & 0,035 & $-3,41$ & 0,001 & $-0,189--0,051$ \\
\hline Aktivitas*pelayanan jasa/pedagang & $-0,136$ & 0,037 & $-3,61$ & 0,000 & $-0,210--0,062$ \\
\hline Aktivitas*TNI/PNS/BUMN & $-0,244$ & 0,061 & $-3,99$ & 0,000 & $-0,364--0,124$ \\
\hline AktivitasTidak bekerja & $-0,115$ & 0,037 & $-3,05$ & 0,002 & $-0,189--0,041$ \\
\hline Aktivitas*merokok & $-0,139$ & 0,043 & $-3,24$ & 0,001 & $-0,224--0,055$ \\
\hline Konstanta & $-4,681$ & 0,038 & $-121,75$ & 0,000 & $-4,757--4,606$ \\
\hline
\end{tabular}

\section{BAHASAN}

\section{Prevalensi obesitas}

Pada penelitian ini ditemukan prevalensi obesitas (> $27 \mathrm{~kg} / \mathrm{m} 2)$ sebesar 12,47 (Cl 95\%: 12,28-12,66) sedikit lebih tinggi dari prevalensi obesitas pada laporan Riskesdas 2007, yaitu sebesar 10,30 persen, ${ }^{15}$ tampak ada perbedaan persentase sebesar 2,17 persen atau di luar dari kisaran confidence interval. Hal ini kemungkinan karena adanya perbedaan proses cleaning data maupun jumlah sampel yang dianalisis.
Kemudian jika dibandingkan dengan prevalensi obesitas pada tahun 1996, yaitu 12,2 persen, ${ }^{13}$ sekilas tidak tampak adanya peningkatan kasus obesitas selama kurang lebih 10 tahun. Hal ini dikarenakan survei IMT pada tahun 1996 hanya dilakukan di 12 wilayah perkotaan di Indonesia, di mana pada penelitian ini juga menemukan prevalensi obesitas di wilayah perkotaan sebesar 15,99 persen. Dengan demikian sesungguhnya terdapat peningkatan persentase obesitas sebesar 3,79 persen untuk wilayah perkotaan di Indonesia. Sedangkan prevalensi obesitas di wilayah 
perdesaan di Indonesia didapatkan sebesar 9,54 persen. Dengan kata lain kejadian obesitas tidak hanya menjadi masalah kesehatan di wilayah perkotaan saja, namun kecenderungan peningkatan kasus obesitas di perdesaan juga perlu menjadi bahan masukan dalam membuat kebijakan dan perencanaan program gizi dan kesehatan. Program pencegahan obesitas tidak hanya menjadi prioritas program di perkotaan saja, namun juga di perdesaan.

Selanjutnya dengan menggunakan cut off yang sama (> $27 \mathrm{~kg} / \mathrm{m}^{2}$ ) prevalensi obesitas di Indonesia tampak lebih tinggi dibandingkan dengan prevalensi obesitas di Pakistan pada tahun 2006, yaitu sebesar 10,3 persen (Cl 95\%: 7,0-13,2), walaupun jika dilihat dari confidence interval tampak tidak jauh berbeda. ${ }^{5}$

\section{Hubungan aktivitas fisik dan obesitas}

Pada penelitian ini menyimpulkan bahwa setelah dikontrol confounder variables (variabel wilayah, umur, jenis kelamin, status kawin, pendidikan, pekerjaan, dan kebiasaan merokok) diketahui bahwa risiko kejadian obesitas pada orang dewasa berbeda menurut vriabel jenis kelamin, pendidikan, pekerjaan, dan kebiasaan merokok.

Dari variabel jenis kelamin diketahui bahwa risiko obesitas lebih tinggi pada laki-laki yang aktivitas fisiknya kurang $(\mathrm{OR}=1,59)$ dibandingkan dengan perempuan yang aktivitas fisiknya kurang $(O R=1,29)$. Hasil penelitian ini tidak jauh berbeda dengan penelitian Kaplan, et al.(2003) yang mendapatkan hasil bahwa risiko obesitas pada laki-laki dengan aktivitas fisik kurang sebesar 2,49 kali (Cl 95\%: 1,65-3,75) dibandingkan dengan laki-laki dengan aktivitas fisik cukup. Sedangkan risiko obesitas pada perempuan dengan aktivitas fisik kurang sebesar 1,85 kali (Cl 95\%: 1,65-2,07) dibandingkan dengan perempuan dengan aktivitas fisik cukup. ${ }^{20}$

Demikian juga menurut Health Survey for England (HSE) yang juga menemukan bahwa prevalensi obesitas pada laki-laki dengan aktivitas fisik kurang lebih tinggi dibandingkan dengan laki-laki yang aktivitas fisiknya cukup $(28,3 \%$ dan $17,8 \%)$, sedangkan prevalensi obesitas pada perempuan dengan aktivitas fisik kurang cenderung lebih tinggi dibandingkan dengan perempuan dengan aktivitas fisik cukup $(29,2 \%$ dan $16,0 \%){ }^{21}$
Menurut pendidikan, diketahui bahwa risiko obesitas lebih tinggi pada responden dengan pendidikan $\leq$ SD yang aktivitas fisiknya kurang $(\mathrm{OR}=1,59)$ dibandingkan dengan responden dengan pendidikan SMP $(\mathrm{OR}=1,37)$, dan SMA ke atas $(O R=1,41)$ yang aktivitas fisiknya kurang. Hasil penelitian ini sejalan dengan beberapa penelitian sebelumnya yang menyatakan bahwa pendidikan yang rendah berhubungan dengan kejadian obesitas. ${ }^{22,23}$ Lebih lanjut Berg (1985) menyatakan bahwa masalah gizi seringkali timbul karena ketidaktahuan atau kurangnya informasi mengenai zat gizi yang memadai. Orang yang berpendidikan kurang lebih mementingkan rasa dan harga daripada nilai gizi makanan. Sebaliknya dengan kurangnya daya beli seseorang masih dapat memenuhi kebutuhan gizinya bila tahu cara memanfaatkan semua sumber daya yang ada. ${ }^{24}$

Selanjutnya menurut jenis pekerjaan diketahui bahwa risiko obesitas lebih tinggi pada responden yang bekerja sebagai petani/buruh/nelayan dengan aktivitas fisik kurang $(O R=1,59)$ dibandingkan dengan responden yang bekerja di bidang pelayanan jasa/pedagang (OR=1,39), TNI/PNS/BUMN $(\mathrm{OR}=1,25)$, dan responden tidak bekerja $(O R=1,42)$ dengan aktivitas fisik kurang. Menurut Prentice and Jebb (2004), aktivitas fisik yang kurang bagi pekerja selama bekerja merupakan prediktor yang kuat dari peningkatan berat badan, kemudahan transportasi kendaraan bermotor ikut berkontribusi dalam meningkatnya obesitas. Hasil penelitian lain juga menunjukkan bahwa indikator dari kurangnya aktivitas fisik (seperti: waktu yang dihabiskan waktu menonton TV dan atau mengendarai mobil) lebih dekat hubungannya dengan prevalensi obesitas daripada asupan energi atau lemak. Studi di Amerika dan Australia juga menunjukkan bahwa menonton televisi merupakan proxy yang signifikan yang berkontribusi terhadap perkembangan obesitas. ${ }^{25}$

Secara teori dapat dijelaskan bahwa bentuk tubuh orang yang jenis pekerjaannya tidak banyak mengeluarkan energi akan berbeda dengan orang yang pekerjaannya selalu menggunakan otot atau banyak melakukan aktivitas fisik. Dengan kata lain penggunaan energi bervariasi pada tingkat aktivitas fisik dan pekerjaan yang berbeda. Aktivitas fisik akan 
membakar energi dalam tubuh. Dengan demikian jika asupan kalori ke dalam tubuh berlebihan dan tidak diimbangi dengan aktivitas fisik yang seimbang akan menyebabkan tubuh mengalami kegemukan. ${ }^{26,27}$

Lebih lanjut dijelaskan bahwa ada tiga komponen dari pengeluaran energi, yaitu: REE (Resting Energy Expenditure), TEM (Thermic Effect of Meals or Food), EEPA (Energy Expenditure resulting from Physical Activity). Tataranni dan Ravussin (2002) mengemukakan bahwa untuk sedentary pada orang dewasa REE-nya sebesar $60-70 \%$ dan TEM-nya sebesar 10 persen dari total pengeluaran energi setiap hari. Sedangkan EEPA sangat bervariasi antar individu dengan jenis pekerjaan dan aktivitas fisik yang berbeda, oleh karena itu memungkinkan terjadinya pengeluaran energi yang berakibat pada pengontrolan berat badan. Karena olahraga dan aktivitas fisik waktu luang berkontribusi kepada EEPA, maka target intervensi pada komponen pengeluaran energi ini mempunyai dampak yang berarti pada pengurangan berat badan. ${ }^{28}$

Sedangkan menurut kebiasaan merokok ditemukan bahwa risiko obesitas lebih tinggi pada responden dengan kebiasaan merokok yang aktivitas fisiknya kurang $(O R=1,59)$ dibandingkan dengan responden yang tidak merokok dan aktivitas fisiknya kurang $(\mathrm{OR}=1,39)$. Secara teori dapat dijelaskan bahwa terjadinya obesitas terkait dengan asupan energi yang berlebihan dan aktivitas fisik yang kurang yang dilakukan oleh responden yang merokok. Dari perspektif kesehatan masyarakat, dua perilaku ini penting karena setiap individu dapat memodifikasi asupan energi dan pengeluaran energinya. Perubahan pada perilaku tersebut dapat mengakibatkan penambahan berat badan yang signifikan. ${ }^{29}$ Selanjutnya Canoy et al. ${ }^{30}$ menyatakan bahwa merokok berhubungan dengan peningkatan kejadian obesitas yang mencerminkan konsekuensi metabolik dari merokok.

Secara umum dapat ditambahkan bahwa aktivitas fisik yang kurang menjadi faktor risiko utama terjadinya kelebihan berat badan dan obesitas, walaupun studi cross-sectional hanya menemukan hubungan yang moderate antara tingkat aktivitas fisik dengan status berat badan, namun pada studi prospektif menyimpulkan adanya hubungan antara kurangnya aktivitas fisik dengan tingginya penambahan berat badan. ${ }^{31}$

\section{SIMPULAN DAN SARAN}

\section{Simpulan}

Berdasarkan hasil dan pembahasan penelitian tentang hubungan aktivitas fisik dengan kejadian obesitas pada orang dewasa, maka dapat disimpulkan sebagai berikut:

1. Prevalensi obesitas (IMT> $27 \mathrm{~kg} / \mathrm{m}^{2}$ ) didapatkan sebesar 12,47 persen.

2. Terdapat hubungan aktivitas fisik dan kejadian obesitas pada orang dewasa setelah dikontrol oleh confounder variables, seperti: wilayah, umur, jenis kelamin, status kawin, pendidikan, pekerjaan, dan kebiasaan merokok.

3. Risiko obesitas lebih tinggi pada laki-laki yang melakukan aktivitas fisikkurang $(\mathrm{OR}=1,59)$ dibandingkan dengan perempuan yang melakukan aktivitas fisik kurang $(O R=1,29)$.

4. Risiko obesitas lebih tinggi pada responden dengan pendidikan $\leq S D$ yang aktivitas fisiknya kurang $(\mathrm{OR}=1,59)$ dibandingkan dengan responden dengan pendidikan SMP $(O R=1,37)$, dan SMA ke atas $(O R=1,41)$ yang aktivitas fisiknya kurang.

5. Risiko obesitas lebih tinggi pada responden yang bekerja sebagai petani/buruh/nelayan dengan aktivitas fisik kurang $(\mathrm{OR}=1,59)$ dibandingkan dengan responden yang bekerja di bidang pelayanan jasa/pedagang $(\mathrm{OR}=1,39), \quad \mathrm{TNI} / \mathrm{PNS} / \mathrm{BUMN} \quad(\mathrm{OR}=1,25)$, dan responden tidak bekerja $(\mathrm{OR}=1,42)$ dengan aktivitas fisik kurang.

6. Risiko obesitas lebih tinggi pada responden dengan kebiasaan merokok yang aktivitas fisiknya kurang $(O R=1,59)$ dibandingkan dengan responden yang tidak merokok dan aktivitas fisiknya kurang $(\mathrm{OR}=1,39)$.

\section{Saran}

1. Hasil penelitian diharapkan dapat menjadi masukan bagi Direktorat Gizi Departemen Kesehatan dalam membuat kebijakan program gizi terkait dengan upaya pencegahan terjadinya kelebihan berat badan dan obesitas di Indonesia baik di perkotaan maupun di perdesaan. Program pencegahan kelebihan berat badan dan obesitas melalui peningkatan aktivitas fisik 
sehari-hari, yaitu: aktivitas fisik berat 3 hari per minggu selama 20 menit $(60$ menit per minggu), aktivitas fisik sedang 5 hari per minggu selama 30 menit (150 menit per minggu), perlu segera disosialisasikan ke Dinas Kesehatan Kabupaten/Kota maupun ke sekolah-sekolah dan instansi pemerintah lain. Di samping itu juga diperlukan kerja sama lintas program dengan Bagian Promosi Kesehatan Depkes untuk penyebaran informasi baik lewat media cetak maupun media elektronik.

2. Bagi peneliti, diharapkan dapat menjadi bahan masukan untuk penelitian lanjutan terkait dengan aktivitas fisik dan obesitas. Perlunya penelitian lanjutan untuk membuat pedoman yang baku terkait dengan kecukupan aktivitas fisik yang dilakukan oleh responden.

\section{RUJUKAN}

1. Lee YS, So JBY, Deurenberg-Yap M. Confronting the obesity epidemic: Call to arms. Ann Acad Med 2009; 38(1): 1-2.

2. Obesity: Preventing and Managing the Global Epidemic. Report of a WHO Consultation. World Health Organ Tech Rep Ser 2000; 894: 1-253.

3. Kumanyika SK, Obarzanek E, Stettler N, Bell $R$, Field $A E$, Fortmann $S P$ et al. Population-based prevention of obesity. The need for comprehensive promotion of healthful eating, physical activity, and energy balance: A Scientific Statement from American Heart Association Council on Epidemiology and Prevention, Interdisciplinary Committee for Prevention (formerly the Expert Panel on Population and Prevention Science). Circulation. 2008; 118: 428-64.

4. Truesdale KP, Stevens J, Lewis CE, Schreiner PJ, Loria CM, Cai J. Changes in risk factors for cardiovascular disease by baseline weight status in young adults who maintain or gain weight over 15 years: the CARDIA study. Int J Obesity 2006; 30: 1397-1407.

5. Jafar TH, Chaturvedi N, Papps G. Prevalence of overweight and obesity and their association with hypertension and diabetes mellitus in an Indo-Asian population. CMAJ. 2006; 175(9): 1071-7.
6. Mokdad AH, Ford ES, Bowman BA, Dietz WH, Vinicor F, Bales VS et al. Prevalence of obesity, diabetes, and obesity-related health risk factors, 2001. JAMA. 2003, 289 (1): 76-9.

7. Wolk A, Gridley G, Svensson M, Nyren O, McLaughlin JK, Fraumeni JF et al. A prospective study of obesity and cancer risk (Sweden). Cancer Causes Control. 2001, 12(1): 13-21.

8. Peeters A, Barendregt JJ, Willekens $F$, Mackenbach JP, Al Mamun A, Bonneux L et al. Obesity in adulthood and its consequences for life expectancy: a lifetable analysis. Ann Intern Med. 2003; 138(1): 24-32.

9. Low S, Chin MC, Deurenberg-Yap M. Review on epidemic of obesity. Ann Acad Med Singapore. 2009; 38: 57-65.

10. Cutter J, Tan BY, Chew SK. Levels of cardiovascular disease risk factors in Singapore following a national intervention programme. Bull World Health Organ. 2001, 79:908-15.

11. Lim TO, Ding LM, Zaki M, Suleiman AB, Fatimah S, Siti $S$ et al. Distribution of body weight, height and body mass index in a national sample of Malaysian Adults. Med J Malaysia. 2000; 55(1): 108-28.

12. Ke-You G Da-Wei F. The magnitude and trends of under- and over-nutrition in Asian countries. Biomed Environ Sci. 2001; 14(12): 53-6.

13. Kodyat, dkk. Survei Indek Massa Tubuh (IMT) di 12 Kotamadya, Indonesia. Gizi Indon. 1996, 21: 52-61.

14. Departemen Kesehatan. Petunjuk Teknis Pemantauan Status Gizi Orang Dewasa dengan Indeks Massa Tubuh (IMT). Jakarta: Depkes, 2003.

15. Badan Litbang Kesehatan Departemen Kesehatan. Riset Kesehatan Dasar (Riskesdas) 2007: Laporan Nasional. Jakarta: Badan Litbangkes Depkes, 2008.

16. Harahap H. Pengaruh Diet Penurunan Berat Badan dan Tekanan Darah pada Penderita Prahipertensi yang Kegemukan. Disertasi. Bogor: Sekolah Pasca Sarjana Institut Pertanian Bogor, 2009.

17. Tee E-S. Priority nutrition concerns in Asia. Food and Nutr Bull. 2002, 23 (4): 345-8.

18. Almatsier S. Prinsip Dasar IImu Gizi. Jakarta: Gramedia Pustaka Utama, 2005. 
19. Kruger J, Ham SA, Prohaska TR. Behavioral risk factors associated with overweight and obesity among older adults: the 2005 National Health Interview Survey. Prev Chronic Dis. 2009, 6(1): 1-17.

20. Kaplan MS, Huguet N, Newsom JT, McFarland $\mathrm{BH}$, Lindsay J. Prevalence and correlates of overweight and obesity among older adults: Findings from the Canadian National Population Health Survey. Journal of Gerontology: Medical Sciences. 2003, 58A. (11): 1018-30.

21. http://www.ic.nhs.uk/pubs/hseupdate05/co mmentary/file. Health Survey for England (2005) Latest trend data.

22. Panagiotakos DB, Pitsavos C, Chrysohoou, Risvas G, Kontogianni MD, Zampelas A et al. Epidemiology of overweight and obesity in a Greek adult population: the ATTICA Study. Obes Res. 2004. 12: 1914-20.

23. Janghorbani $M$, Amini $M$, Willett $W C$, Gouya MM, Delavari A, Alikhani $S$ et al. First nationwide survey of prevalence of overweight, underweight, and abdominal obesity in Iranian adult. Obesity. 2007, 15: 2797-2808.

24. Berg, Alan dan Muscat JR. (1985). Faktor Gizi (Terjemahan oleh Sediaoetama), Bhratara Karya Aksara, Jakarta.
25. Salmon J, Bauman A, Crawford D, Timperio $A$, Owen $N$. The association between television viewing and overweight among Australian adults participating in varying levels of leisure-time physical activity. Int J Obes. 2000, 24(5): 600-6.

26. Wirakusumah, Emma S. (1994). Cara Aman dan Efektif Menurunkan Berat Badan, Gramedia, Jakarta.

27. Kantachuvessiri A, Sirivichayakul C, KaewKungwal J, Tungtrongchitr R, Lotrakul M. Factors associated with obesity among workers in a metropolitan waterworks authority. Southeast Asian J Trop Med Public Health. 2005, 36(4): 1057-65.

28. Tataranni PA, Ravussin E. Energy metabolism. In: Wadden TA, Stunkard AJ, eds. Handbook of Obesity Treatment. New York: The Guilford Press, 2002.

29. Galuska D A, Khan L. Obesity: a public health perspective. In: Present Knowledge in Nutrition. $8^{\text {th }}$ Edition. Washington DC: ILSI Press, 2001.

30. Canoy D, Wareham N, Luben R, Welch A, Bingham S, Day N, et al. Cigarette smoking and fat distribution in 21,828 British men and women: a population-based study. Obes Res. 2005, 13(8): 1466-75.

31. Dishman RK, Washburn RA, Health GW. Physical Activity Epidemiology. Champaign: Human Kinetics, 2004. 